\title{
Magdalena. Ensayo de novela de Manuel Cayetano Zetino
}

\author{
Presentación y notas de Jesús Morales-Bermúdez
}

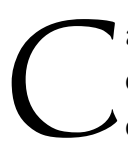

ada pueblo, nación, país, cuenta con bagajes culturales o acervos patrimoniales en los cuales afincar el orgullo de su identidad, las formas históricas de su propia constitución. Pasar de las formas elementales a aquellas en que se traza el espíritu humano y su estatura, como plantean las tradiciones griega y hebraica de nuestro origen," conlleva un necesario recorrido simbólico con expresiones de carácter visual, material, sígnico, gráfico, lúdico, numinoso, en que la lingüística y la literatura cuentan con lugar privilegiado, toda vez de ser ellas la nave en que bogan las explicaciones del ser en el mundo. La nave de significación es, a la vez, una hermenéutica - aquello que significa y lo que es significado- - y una paideia - formación y enseñanza del espíritu humano- Como tales, retazos en progresión. Para los casos de Chiapas, de San Cristóbal en particular, retazos de tradición literaria en que se muestran momentos de su formulación, que los ha habido desde algún tiempo atrás.

Ya en la época colonial, se llevó a cabo escenificaciones doctrinales en parroquias y doctrinas, como ejemplifican algunos "Entremeses" dados a conocer por la estudiosa Dolores Aramoni Calderón (1986). Dentro de las circunstancias excéntricas de la entidad, la emulación de aquellos notables entremeses hispanos que acompañaban a los autos sacramentales vieron, pues, emulación, para anteceder a alguna celebración religiosa particular como la del Corpus Christi o alguna predicación. Y si bien poco hemos conocido del papel didascálico asignado a la literatura colonial, pervivencias encontramos en la literatura posterior. Cierta herencia de corte hermenéutico y de paideia.

El siglo XIX reviste relevancia para la entidad chiapaneca pues se determina en él la apuesta histórica de su pertenencia a la nación mexicana y la pronta necesidad de significarse como mexicana. Sus políticos e intelectuales serán parte de los debates en que se forman los trazos de la nación y su diálogo con el mundo: desde, por lo menos, Matías de Córdova (1766-1828) y Manuel Larráinzar (18091884), figuras tutelares de la mexicanidad en Chiapas, hasta Ángel Albino Corzo (1816-1897) y Nicolás Ruiz, combatientes de los conservadores y de la intervención francesa. Ellos y muchos como ellos publicaron libros o tratados sobre las preocupaciones de su época. En algunos casos de carácter político, histórico, diplomático y educativo. También literario, como en el caso particular de Matías de Córdova, cuya fábula "El león y el éxito de su empresa" permite también ser leída cual reflexión política de cómo un león chiapaneco

Jesús Morales Bermúdez. Centro de Estudios Superiores de México y Centroamérica de la Universidad de Ciencias y Artes de Chiapas. Correo electrónico: memorial.87@hotmail.com

Recibido: 19 de abril de 2017 
—nación chiapaneca- puede ser maniatado por la trampa perspicaz de los hombres de oficio, en el caso, los políticos mexicanos. ${ }^{2}$ Algo similar trata la fuente de donde la fábula probablemente proviene. ${ }^{3}$

Precisamente la literatura encuentra sitial de relieve en la segunda mitad de aquel siglo. Baste dar cuenta, a más de Matías de Córdova, de Rodulfo Figueroa, el poeta modernista par de Darío y su coetáneo, si bien malogrado en juventud; ${ }^{4}$ de Flavio Antonio Paniagua (1844-1911), iniciador de la novela en Chiapas — quien se cuenta además como cronista de las guerras de intervención-, y de Emilio Rabasa (1856-1930), el prolífico y sólido novelista, clasificado como el introductor del realismo literario en el país. Las trayectorias de los escritores anteriores han sido reconocidas en el contexto de las letras y sus trabajos cuentan con estudios valorativos y con ediciones modernas.

Hay, a la par de aquella notable literatura decimonónica, una literatura también menor inscrita en la conciencia de desempeñar el papel didascálico de buena parte de la literatura religiosa colonial. ${ }^{5}$ Dentro del rubro se encuentra el documento que ofrecemos en la presente entrega: Magdalena. Ensayo de novela.

"El fin de la novela", escribe el propio autor en su introducción, "no es otro que el de instruir agradando y moralizar a los lectores bajo todos los modos posibles [e] infundir de algún modo el amor a la virtud y el odio al vicio". Ambos propósitos sostienen la trama del relato. En cuanto al autor, se sitúa a sí mismo como alguien carente de talentos literarios pero con indudable sinceridad moralizante, edificante y, aun cuando no lo afirma, como un educador. ${ }^{6}$ Con esa conciencia, traza el mapa de su novela, para nada complicado, si bien con algunos registros en torno al tema central: los comportamientos matrimoniales según se inscriben y deben inscribirse bajo la guía de la Iglesia católica.

A lo largo de la vida colonial, uno de los temas de mayor preocupación para la Iglesia católica fue el del matrimonio, institución no alcanzada a formar en la Nueva España a la manera monógama instituida por el Concilio de Trento, ${ }^{7}$ y prosiguió con ambigüedades. Surgió, además, el matrimonio civil como único reconocido, en México, de acuerdo con las Leyes de
Reforma de Juárez de 1855. La novela que nos ocupa, publicada en 1889 , tiene como telón de diálogo esas leyes y el emergente sentido liberal en miembros de la sociedad, en la cual cobra nivel de prestigio declararse librepensador, muy a pesar de las ambigüedades privadas de cada persona, así como del propio Juárez y de políticos locales, tal el caso de Flavio Guillén, gobernador de Chiapas, quien "a más del acto civil, quiso la ceremonia religiosa presidida por el obispo Orozco y Jiménez". ${ }^{8}$

En ambos, contexto y telón de fondo, el autor, Pbro. Manuel Cayetano Zetino $(+1910),{ }^{9}$ desarrolla su novela de doce capítulos — cual doce apóstoles - en apenas cincuenta y ocho páginas, nominándolos, de manera secuencial con numeración romana de la siguiente manera: I. La familia; II. La escuela; III. La primera comunión; IV. El cambio; V. El baile; VI. El insomnio; VII. El segundo baile; VIII. El duelo; IX. La muerte; X. El entierro; XI. La desgracia; XII. Amelia en casa de Magdalena.

Puede, desde los nominales mismos, tenerse una idea de su contenido por cuanto pocos escolios haremos. Sobre la familia, la novela presenta aquella monógama considerada como modelo: nobleza en los padres por ascendencia, "ambos de nobles progenitores"; el ideal de dos o tres hijos, causa de "dicha y felicidad"; con posesión de bienes materiales, dos fincas "de las más ricas del estado", varias casas. Su comportamiento se corresponde al de una familia cristiana, católica, con frecuencia hacia los sacramentos y asistencia a misa diaria y los domingos y días de guardar. En el caso de la novela, como quizás ocurriera en las familias de entonces, los primeros hijos son arrancados de la casa por "una enfermedad epidémica"10 que deja desolada a la ciudad; nace María Magdalena, "linda criatura esta, parece un ángel”. María Magdalena, nombre retraído de la pecadora de los Evangelios, es una mujer centro de la atención de sus padres, de las personas en su entorno, de la novela. Funge como epicentro desde el cual conocemos usos de la época, narrados en la novela.

La educación formal, particularmente la educación formal para mujeres es punto primero. Para la época, escribe el narrador, "la educación de la mujer se tenía 
como una de las cosas innecesarias [...] pues se creía que con poseer los conocimientos más comunes, como algo de lectura y algunas veces nada de escritura, era lo suficiente para que se tuviera como apta e ilustrada"." Existe una sola escuela municipal y a ella la inscriben. Vive la extrañeza de cada infante en su tránsito del hogar al espacio de socialización; se relaciona, hace amistad con Amelia, "niña recomendable por su piedad y honradez [...] en su alma habitaba la inocencia”; se hacen compañía, "asistiendo juntas a la escuela, adelantando iguales en todos los ramos de enseñanza, principalmente en las cuentas, geografía, tejidos y bordados".

Una de las prácticas favorecida por la Iglesia desde tiempo inmemorial es el de la Eucaristía, centro de su celebración, de su credo. El memorial de la cena última de Jesús y sus apóstoles fue instituido como sacramento por el Concilio de Trento, bajo una regulación, a la cual acceden Magdalena y Amelia, con ocasión de su primera comunión. El suceso como tal de la primera comunión, memorable en obras literarias de lengua española como en La arboleda perdida de Rafael Alberti, procura el narrador hacerla memorable en su novela, pues se permite rasgos de lirismo, de adjetivación, de mostrarse omnisciente de las pulsiones emocionales de los protagonistas, de la madre "señora de costumbres puras, ilustrada y virtuosa", del padre, señor Monterrosa, quien exhorta a las niñas a perseverar en la inocencia para garantizar su felicidad y la de sus padres. La emotiva ceremonia concluye, como en La arboleda perdida y en la película El sur, con un festejo doméstico, "tomar chocolate", quizás tamales, pan, en "la casa decentemente adornada, desde el zaguán hasta el comedor habían colocado graciosos arcos de flores y con las que alfombraban el pavimento, esparcían un olor agradable; el piano resonaba con gratas armonías: todos los parientes se reunieron para celebrar tan fausto día y los criados de la casa vestidos de limpio, servían con prontitud". Propone, con la comunión, una mejora del comportamiento, como también lo consideraba Wittgenstein por esos años, y la contrapone con "la lepra del pecado".

La primera comunión ha sido el momento culmen de una vida de decoro. La novela extiende el manto de una transformación de esa familia, originada por el padre, quien, merced a su contacto con personas distantes de sus prácticas anteriores, "conversando, jugando, leyendo periódicos, discutiendo algunos asuntos científicos, civiles y religiosos", ${ }^{12}$ estableció una distancia progresiva de su práctica religiosa, modificó sus hábitos y horas de presencia en casa, “ise hizo libre pensador!" y, con ello, abrió la puerta para que su esposa también se distanciara de aquella vida y que Magdalena "perdía el gusto por las cosas de piedad ${ }^{13}$ [...] Había cambiado la lectura de buenos libros, por novelas amatorias e inmorales, y algunos otros antirreligiosos que tomaba de la biblioteca de su padre". Se distancia de Amelia, quien comprende el cambio y se promete guardad lealtad y ver algún día el triunfo de la amistad.

Prosigue, y es la parte central y extensa de la novela, el relato de la vida mundana de Magdalena, quien vive la excitación de dos bailes y las secuelas cortesanas que se derivan de ellos en una especie de cortejo y enamoramiento que más se trata, para el narrador, de la presencia de sensualidad y erotismo, su invasión. En sí mismo el baile no conlleva carga negativa y es considerado como un momento de relaciones. Dice el señor Monterrosa a su hija: "Entre nosotros, el baile se tiene como propio de una familia culta [...] Allí aprenderás á tratar a toda clase de personas, te ilustrarás y sabrás estar en sociedad, cosa tan importante para una niña de tu clase". La vivacidad que la experiencia le provoca, la conducen a insomnios, ${ }^{14}$ a anhelar ser parte de esa vida, dentro de la cual comienza con citas furtivas, cada vez más ardientes, con sus enamorados, primero César, después Arturo. Aparece Celestina en el personaje Adela, nueva amiga de Magdalena. Sentencia el narrador: "Magdalena va caminando de abismo en abismo y probablemente no suspenderá, sino hasta terminar con su honradez".

El segundo baile es decisivo en el nudo gordiano de la novela. En él se dibuja el carácter de los dos enamorados y sus actitudes ante la dama. Por despecho, César reta a duelo a Arturo. Por ese mismo despecho, "se dirigió a los músicos para suplicarles que tocaran una pieza de las más tristes que tuvieran, 
la que fue ejecutada en el acto". No se realiza el duelo por intervención de los padres de Magdalena y César "por cuanto los dos combatientes eran hijos de dominio", mas la fama honorable de Magdalena se desdibuja. César se desencanta de Magdalena, de su sociedad, y parte de la ciudad. Enferma el padre de Magdalena, ${ }^{15}$ muere sin confesión, ${ }^{16}$ y es enterrado. ${ }^{17}$ Aprovecha el narrador para hacer las distinciones de formas anteriores, al amparo de la Iglesia, y las actuales, más bien liberales. Con la muerte del padre cambia la vida familiar: la madre se retrae y "Magdalena siguió la nueva vida que había adoptado un tiempo antes [...] soñaba diariamente á su Arturo; y él no podía vivir ya sin verla [...] el dios del amor encendió más la hoguera en aquellos corazones, les ofuscó la inteligencia y arrastrados por el ardor de la juventud fueron precipitados a un abismo...!!!” Arturo se va de la ciudad, también hace mutis Adela, la madre muere de pena. Magdalena, "al fin de tantos padecimientos, se vió [sic] con un niño en sus brazos [...] Se trató de bautizarlo y le pusieron por nombre Lázaro". ${ }^{18}$

Hasta ahí la antesala al desenlace, por supuesto edificante. Desde el momento de su "caída" con Arturo, Magdalena cae en continuo llanto, uno de los atributos de la Magdalena de los Evangelios, pues es mujer débil a la carne, otro de sus atributos, y cede a los remordimientos por ello, culpa humana, también atributa de aquella de los Evangelios; se cubre de humildad: "iOh no, soy indigna de que me estimes de nuevo!", le expresa a Amelia cuando llega a su casa, la única entre sus anteriores lazos con la sociedad, "Conozco que te he ofendido demasiado, cambiando tu amistad por la de una mujer traidora y despreciándote como lo hice tantas veces". De la renovada amistad propiciada por Amelia, la Magdalena pecadora surge a nueva vida, como ya anunciaba el recurso evangélico del nombre de su hijo, Lázaro, y dedica sus bienes y vida a una similar vida evangélica activa. Consecuente con el motivo didascálico de su Ensayo de novela, el autor concluye: "Multitud de niños pobres pudieron educarse por ella, muchas niñas huérfanas se libraron de la desgracia y pérdida del honor; muchos matrimonios fueron felices y muchas viudas se conservaron en el temor santo de Dios. Tales bienes produjo el pecado y arrepentimiento de Magdalena!" El autor pondera el peso favorable del pecado, proseguido de arrepentimiento, en referencia, quizás, al enunciado paulino: "La ley, en verdad, intervino para que abundara el delito; pero donde abundó el pecado, sobreabundó la gracia". ${ }^{19}$

Limitaciones literarias de Magdalena. Ensayo de novela, fácilmente las podemos dirimir. También virtudes, como su estilo claro, preciso, sin afeites. No es la razón de su presencia en esta entrega. A más de su interés educacional para un tiempo, es de situarla en su tiempo literario, cuando aparecen dos monumentos de la literatura universal: Ana Karenina, de León Tolstoi, publicada de manera completa el año de 1877 , con éxito inmediato, y Madame Bobary, de Gustave Flaubert, publicada como libro en 1857. En ambas novelas las cuestiones de erotismo, religión y culpa se entreveran con propósitos primordialmente literarios y estéticos. En ambas novelas hay escenas de baile, desdenes, duelos, retirada de algún amante. Por ejemplificar con el baile, tomemos a Tolstoi, a quien parece emular Cayetano Zetino: "el baile transcurrió para ella como un sueño encantador, de alegres colores, de sonidos y movimiento. Solo dejaba de bailar cuando se sentía demasiado cansada y rogaba que la dejasen descansar [...] bailando con un muchacho aburrido, al que no había podido rechazar, se encontró vis-à-vis de Vronsky y de Ana y [...] Vio en Ana aquella excitación, motivada por el éxito que conocía tan bien. Estaba ebria a causa de la admiración que producía..." (Tolstoi, 1956: 67). Quedará la duda de si acaso este modesto autor chiapaneco tuvo acceso a la lectura de los dichos monumentos literarios y de qué manera, si acaso, se situó en similar preocupación mundana, religiosa, que los prominentes autores de las novelas referidas, particularmente de Tolstoi, generador de un cristianismo propio. Duda quizás vana, inútil, que de inutilidad está constituida la poesía, la literatura, las artes, una inutilidad proveedora de espíritu y estatura humanos en los hombres de cada generación y época histórica. Cuáles hayan sido los alcances, la recepción de Magdalena. Ensayodenovela, queda entre los pendientes, como es pendiente contar con ejemplares de su edición 
príncipe, inencontrables actualmente aún en los acervos de la Benson University of Texas at Austin, ${ }^{20}$ que ya es mucho decir. Valga ofrecerla en este número de Liminar. Estudios Sociales y Humanísticos, con el espíritu de los antiguos historiadores locales, para que las "cosas de Chiapas", como decía Fernando Castañón Gamboa, no desaparezcan del todo.

\section{Notas}

${ }^{1}$ La tradición de Occidente se funde en Grecia y el judaísmo-cristianismo: Jaeger (1965); Steiner (2012). Para las cuestiones de espíritu y estatura humana en Esquilo y Sófocles, ver Kott (1970). También, Efesios 4.

${ }^{2}$ En trabajo anterior había escrito: "su poema puede ser leído como una fábula didáctica en que su autor ejemplifica el destino de Chiapas frente a una entidad poderosa, el México de la anexión, ante el cual no tendrá otra posibilidad sino de sumisión: el león Chiapas (por escudo de armas) con las garras hendidas en un tronco, inmovilizado e inutilizado, como no sea por la venia de su dominador. Semejante futuro que avizora, le hace pensar en la anexión a Guatemala o en la permanencia de Chiapas como independiente, hacia un futuro quizás incierto, quizás cabeza de ratón y no cola de león, proposición que resultó inversa de acuerdo con las decisiones de las dirigencias de entonces: "más vale ser cola de león que cabeza de ratón", reza el adagio para el caso de Chiapas en su federación a México" (Morales, 2005a: 40).

3 "Excursión a la historia natural: Historia del pavo real y la oca" Noche 131, en Las mil y una noches (1997: 975-981).

4 Véase el sugerente trabajo, comparativo, breve: Gutiérrez (1966).

${ }^{5}$ Podría considerarse, como ejemplo, los trabajos de los hermanos Cadena (1779 y 1879). Las disertaciones de ambos autores inducen la reflexión en torno a la muerte, al estar preparados, como las Vírgenes prudentes del Evangelio, para ser dignos de la salvación, según fuera el ejemplo del rey Carlos III, cantado a la manera de las Odas de Fray Luis de León.

6 La preocupación educacional del Pbro. Manuel Cayetano Zetino la puede testificar su patrocinio de manuales educativos durante su época. Por ejemplo: "Este método silábico fue publicado en los comienzos de 1841 y sus resultados convincentes se prolongaron hasta el año de 1925. Por mucho tiempo fue considerado libro de texto de las escuelas oficiales. Hemos encontrado la edición de 1906, titulada Método doméstico/ ya experimentado para/ enseñar y aprender/ seguramente/ a leer y escribir/ en sesenta y seis lecciones./ Su autor/ El R. M. P. Fray Víctor María Flores./ del S. O. D. P. de Chiapas./ Adorno tipográfico/ Edición hecha á costa del Señor cura, Rector del Sagrario,/ Prebendado don Manuel Cayetano Zetino,/ con las licencias necesarias... (Contreras, 2001: 49). Fue cura párroco de la Parroquia del Sagrario (San Cristóbal, Rector del Seminario Conciliar de la diócesis de Chiapas, cura párroco de San Marcos Tuxtla).

${ }^{7}$ Ver Ricard (2005: 200-205). También, Zúñiga (2013: 139-178).

${ }^{8}$ Ver Morales (2005b: 56ss).

9 "El reconocimiento en el fallecimiento de clérigos se apreciaba aún en 1910, cuando el párroco de Tuxtla expresó la muerte del prebendado Manuel Cayetano Zetino como 'una pérdida para la Diócesis', dirigiendo al gobernador y al vicario general del cabildo catedralicio sus 'votos de descanso eterno al virtuoso finado y grandes consuelos a la santa iglesia de Chiapas"' (Bermúdez, 2013: 147).

${ }^{10}$ El autor sitúa su novela en el año de 1856 y, con seguridad, hace referencia a "la epidemia de cólera de 1833", de la cual aún existía memoria en la ciudad un siglo después. Sobre todo por los vestigios del antiguo cementerio, convertido en campo aéreo (Francisco Sarabia), del cual se decía había acopiado los restos mortales de quienes fallecieron por causa de esa peste, si bien "el panteón general de la ciudad era el de San Diego, hacia el sur. A mediados de 1897 éste fue clausurado y se declaró la apertura oficial del panteón municipal en la ubicación actual” (Bermúdez, 2013: 137 y 146).

${ }^{"}$ Al hablar en pasado, como refiriéndose a otra época, el narrador-autor deja entrever que en la época suya el modelo educativo ha cambiado y existe participación general de las niñas y mujeres. La ejemplificación de 
comportamientos de Magdalena y Amelia en la novela, se corresponden a la realidad del tiempo de escritura del autor, si bien entre el año de la novela y el de este han transcurrido treinta y tres años.

12 “[... sin leer la refutación (como lo debían hacer) para no confundirse [...]", agrega el narrador, retrayendo la manera tomista de plantear el conocimiento.

${ }^{13}$ Dice párrafos atrás: "con la práctica constante de los actos religiosos su corazón se fortalecía y podía soportar impávida los envates [sic] terribles que contra la inocencia, el pudor y la virginidad hacen de consumo los formidables enemigos de la humanidad, el mundo, el demonio y la carne". De alguna manera anuncia cuanto en la vida de Magdalena ha de ocurrir en la novela.

${ }^{14} \mathrm{La}$ frase "Fatigada por los movimientos á los cuales no estaba acostumbrada", del capítulo VI, recuerdan el verso de la Rima XVIII de Gustavo Adolfo Bécquer: "Fatigada del baile".

${ }^{15}$ Refiere los pasos dados, desde la medicina doméstica al facultativo, recetario, junta de médicos, medicamentos, espera, notario, muerte.

${ }^{16}$ Sirve el texto para conocer algo de las formas mortuorias de la época: "La casa fue adornada con riguroso luto. Colocan el féretro en medio de la sala principal, y alumbrado por cirios encendidos, puestos en hermosos candelabros de oro, se veía también el retrato del difunto. Cada cortina blanca mesclada con crespon [sic] negro, estaba adornada con guirnaldas de ciprés. iAquel lúgubre aparato era conmovedor".

${ }^{17}$ En el mismo tenor, se refiere la forma del cortejo, la detención en una esquina para escuchar el discurso de un orador, quien "dice la oración fúnebre".

${ }^{18}$ Hay una discreta referencia a la Jornada primera, parte II de La vida es sueño, el drama de Pedro Calderón de la Barca ("iAy mísero de mí! iAy infelice!/ [...] qué delito cometí/ contra vosotros naciendo;/ [...] Bastante causa ha tenido/ vuestra justicia y rigor;/ pues el delito mayor/ del hombre es haber nacido."), con las frases sencillas: "iAy! infeliz hijo mío, qué necesidad tenías de padecer en este mundo, y quedarte probablemente solo, sin madre, porque padre no has tenido? iAh! Tu padre es un ingrato, un cruel, que no merece tal nombre. infame!", frases también en similitud en los dramas El zapatero y el rey y Traidor, inconfeso y mártir, de José Zorrilla.

${ }^{19}$ Biblia de Jerusalén, Romanos 5, 20.

${ }^{20}$ Quedo en deuda de gratitud con el colega y amigo, Ignacio Ruiz-Pérez, Ph. D., del Department of Modern Languages University of Texas at Arlington, quien se sumó a mis pesquisas de un original del libro, con el propósito de alcanzar copias de la antepenúltima y penúltima páginas, aunque sin éxito. Alguien, adelante, lo alcanzará.

\section{Referencias}

Aramoni Calderón, Dolores (1986). “Un entremés chiapaneco del siglo XVIII". En Anuario del Centro de Estudios Indígenas, vol. I. Tuxtla Gutiérrez: UNACH.

Bermúdez Hernández, Luz del Rocío (2013). "Honras fúnebres, respuesta histórica de las élites de San Cristóbal de Las Casas". En María Eugenia Claps Arenas y Sergio Nicolás Gutiérrez Cruz (coords.), Formación y gestión del Estado en Chiapas. Algunas aproximaciones históricas. México, UNICACH.

Cadena, Carlos (1879). Honras fúnebres celebradas en Guatemala en honor de Carlos III. Guatemala: Tipografía de Ignacio Beteta.

Cadena, Felipe (1779). Acto de contrición en versos castellanos, Guatemala: s/n.

Contreras García, Irma (2001). Las etnias del estado de Chiapas: castellanización y bibliografías. México: UNAM.

Gutiérrez, Jesús Agripino (1966). Dos poetas hispanoamericanos (Rodulfo Figueroay RubénDarío). Tuxtla Gutiérrez, Chiapas: Sección XXXVII del SNTE.

Jaeger, Werner (1965). Cristianismo primitivo y paideia griega, México: Fondo de Cultura Económica.

Kott, Jan (1970). El manjar de los dioses. México: ERA.

Las mil y una noches (1997), t. I. Versión anotada y cotejada por R. Cansinos Assens. Madrid: Aguilar.

Morales Bermúdez, Jesús (2005a). Meditaciones sobre literatura de Chiapas. Tuxtla Gutiérrez, Chiapas: Secretaría de Educación.

Morales Bermúdez, Jesús (2005b). Entre ásperos caminos llanos. La diócesis de San Cristóbal de Las Casas 1950- 
1995. México: Juan Pablos, UNICACH, UNICH, COCYTECH.

Ricard, Robert (2005). La conquista espiritual de México. México: Fondo de Cultura Económica.

Steiner, George (2012). La poesía del pensamiento. Del helenismo a Celan. México: Fondo de Cultura Económica, Siruela.
Tolstoi, León Nicolaievich (1956). Ana Karenina (18731876). En Obras completas Tomo II. Versión directa del ruso, prólogo biográfico y notas por Irene y Laura Andresco. Madrid: Aguilar.

Zúñiga Zenteno, Magda Estrella (2013). La casa chica en Chiapas. Una aproximación antropológica. México: Juan Pablos. 

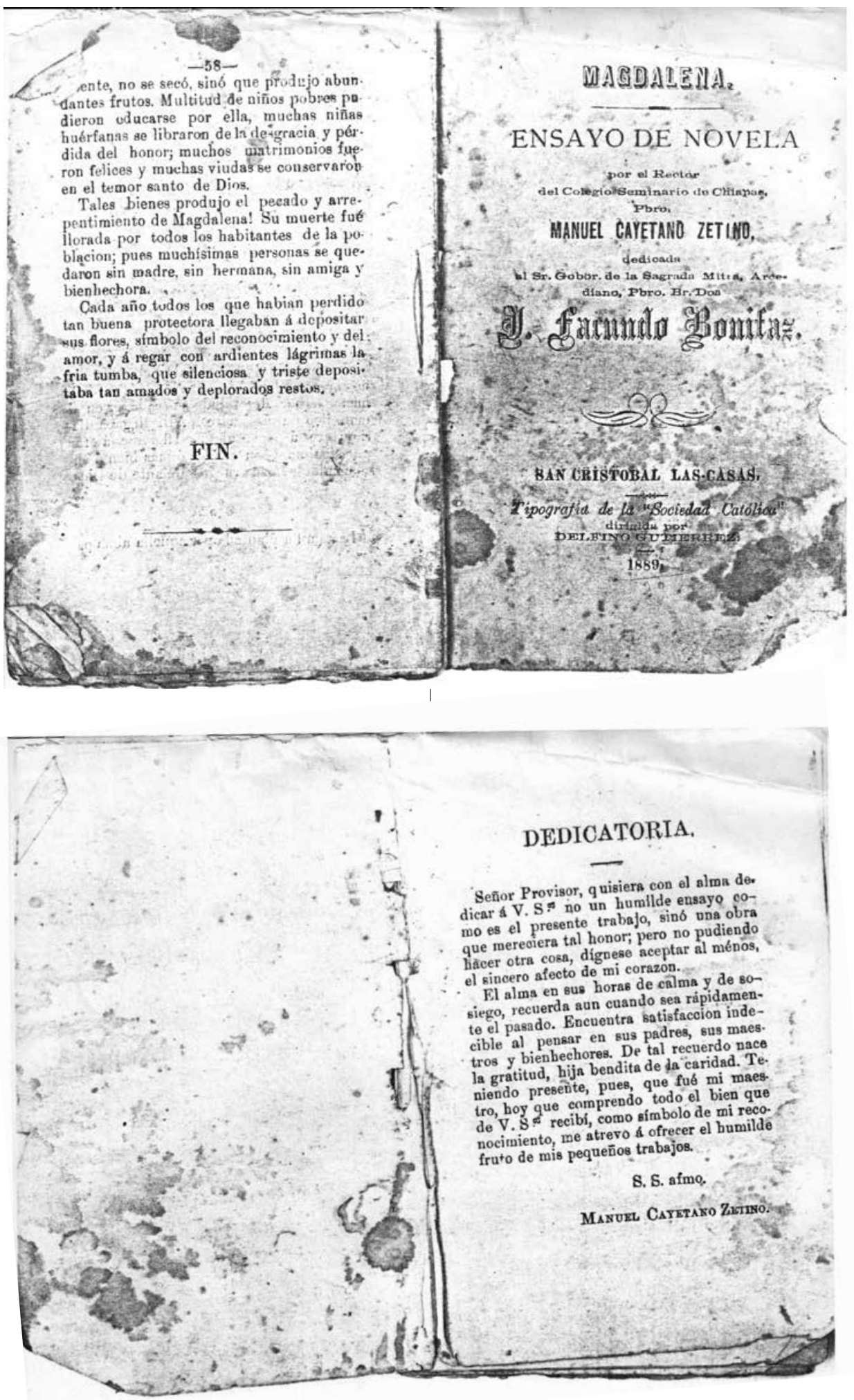


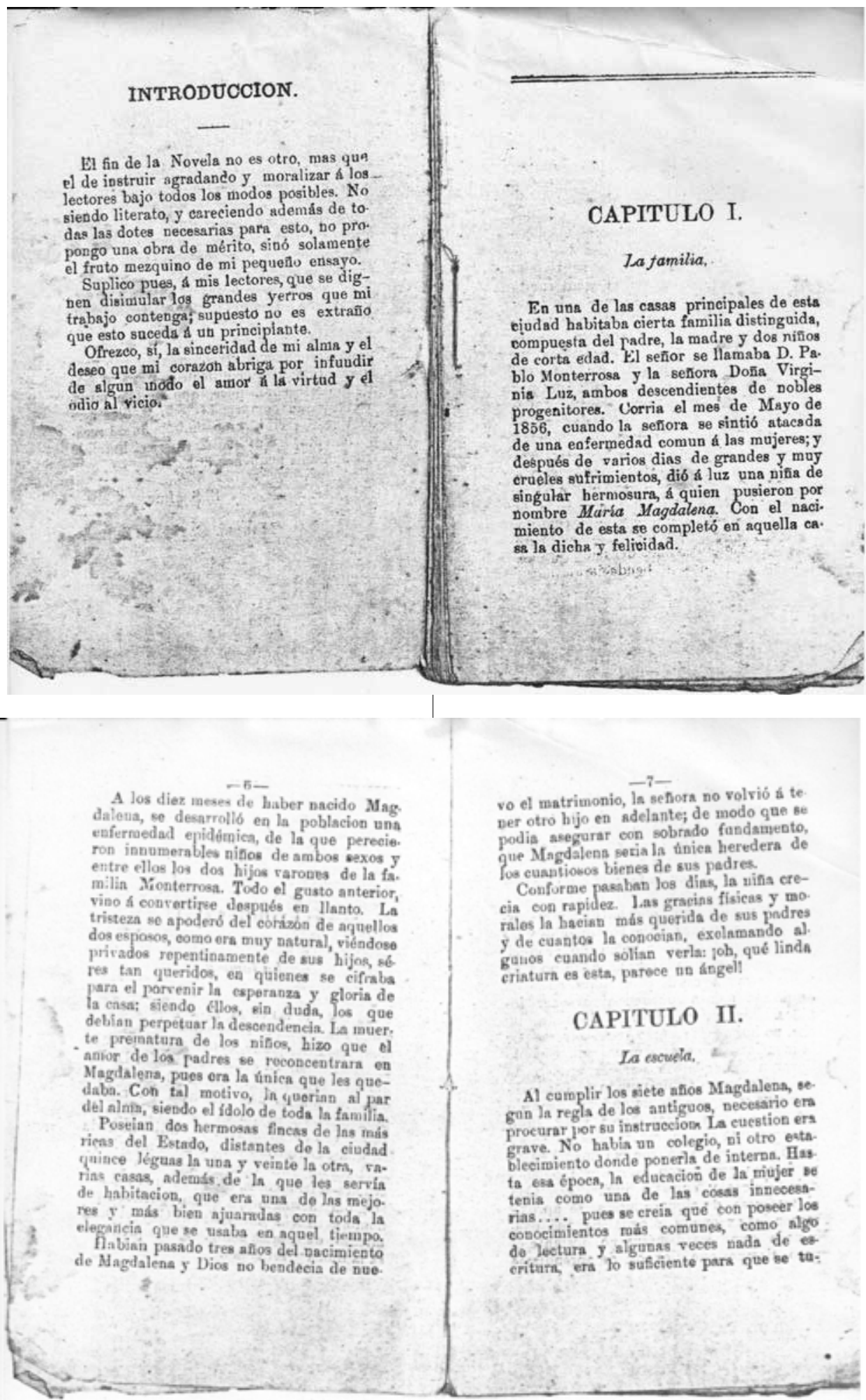




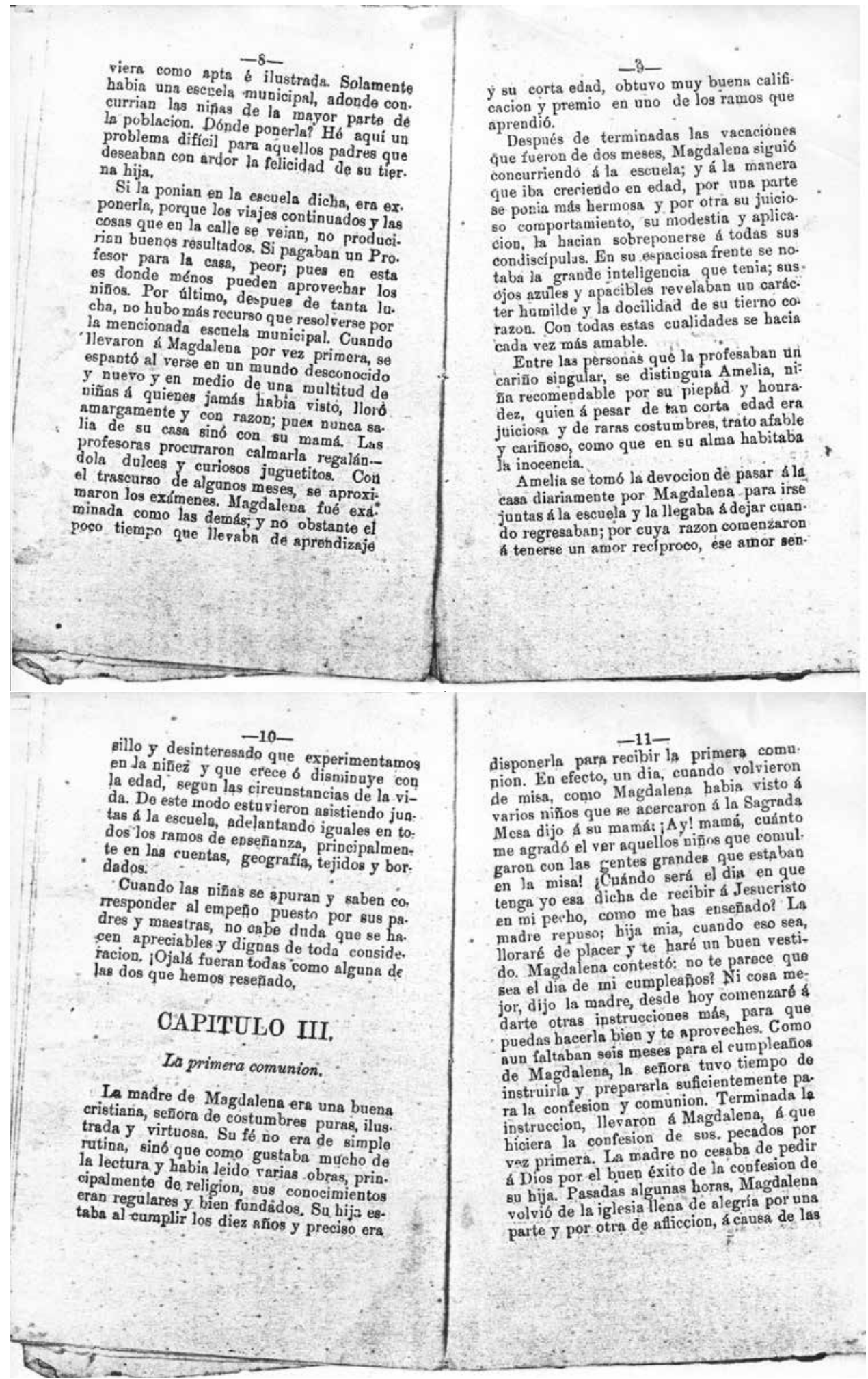




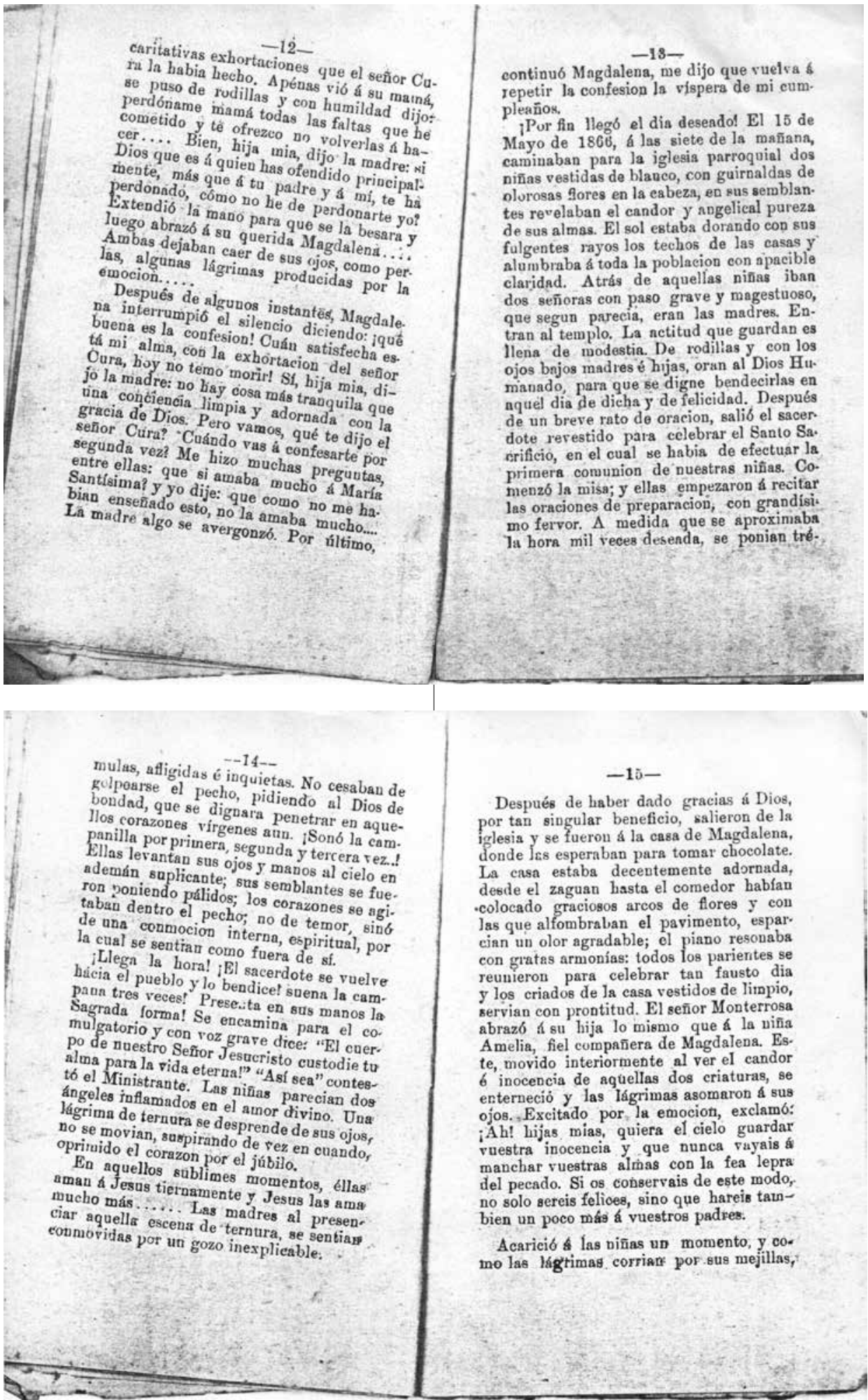




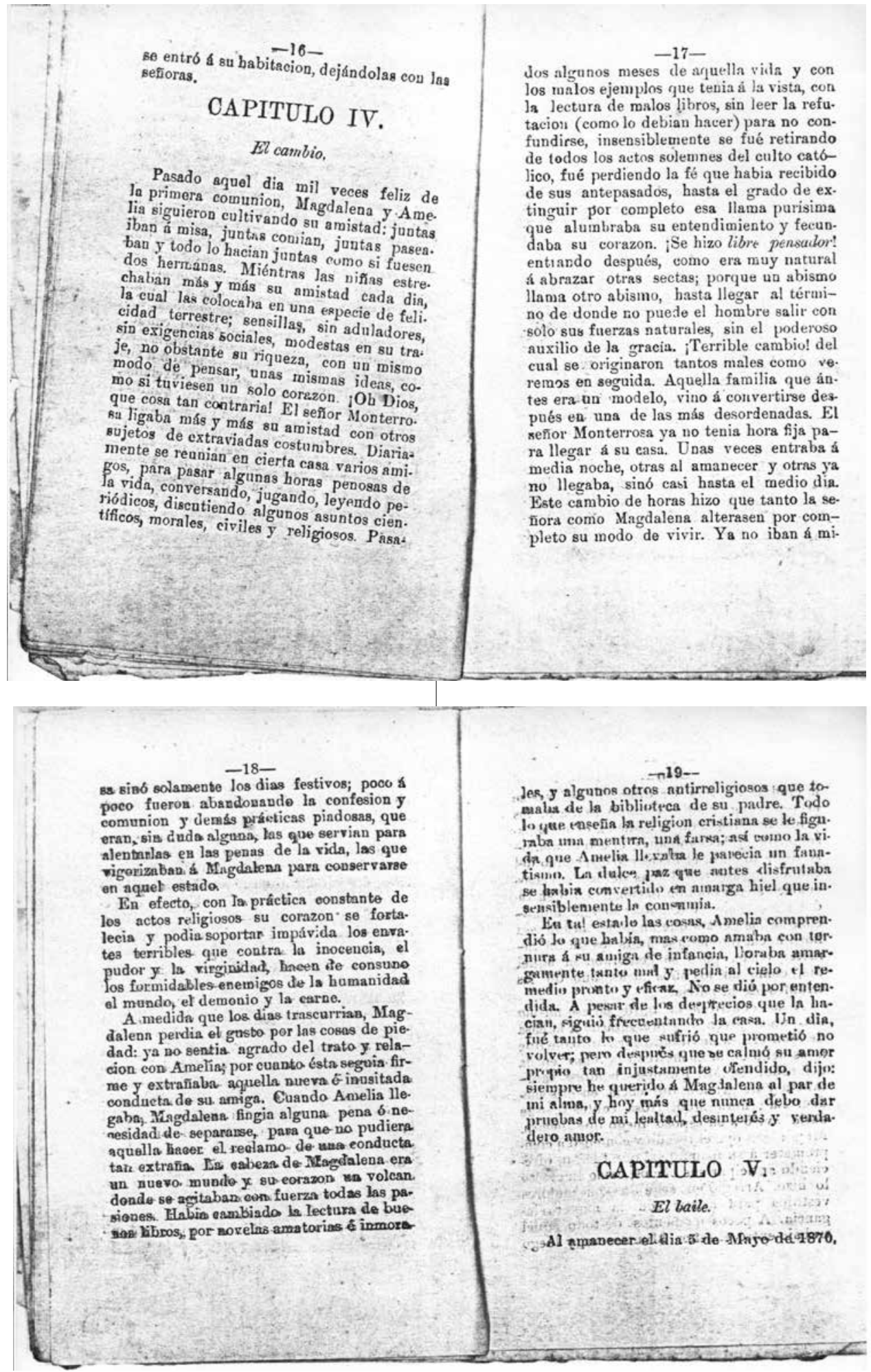




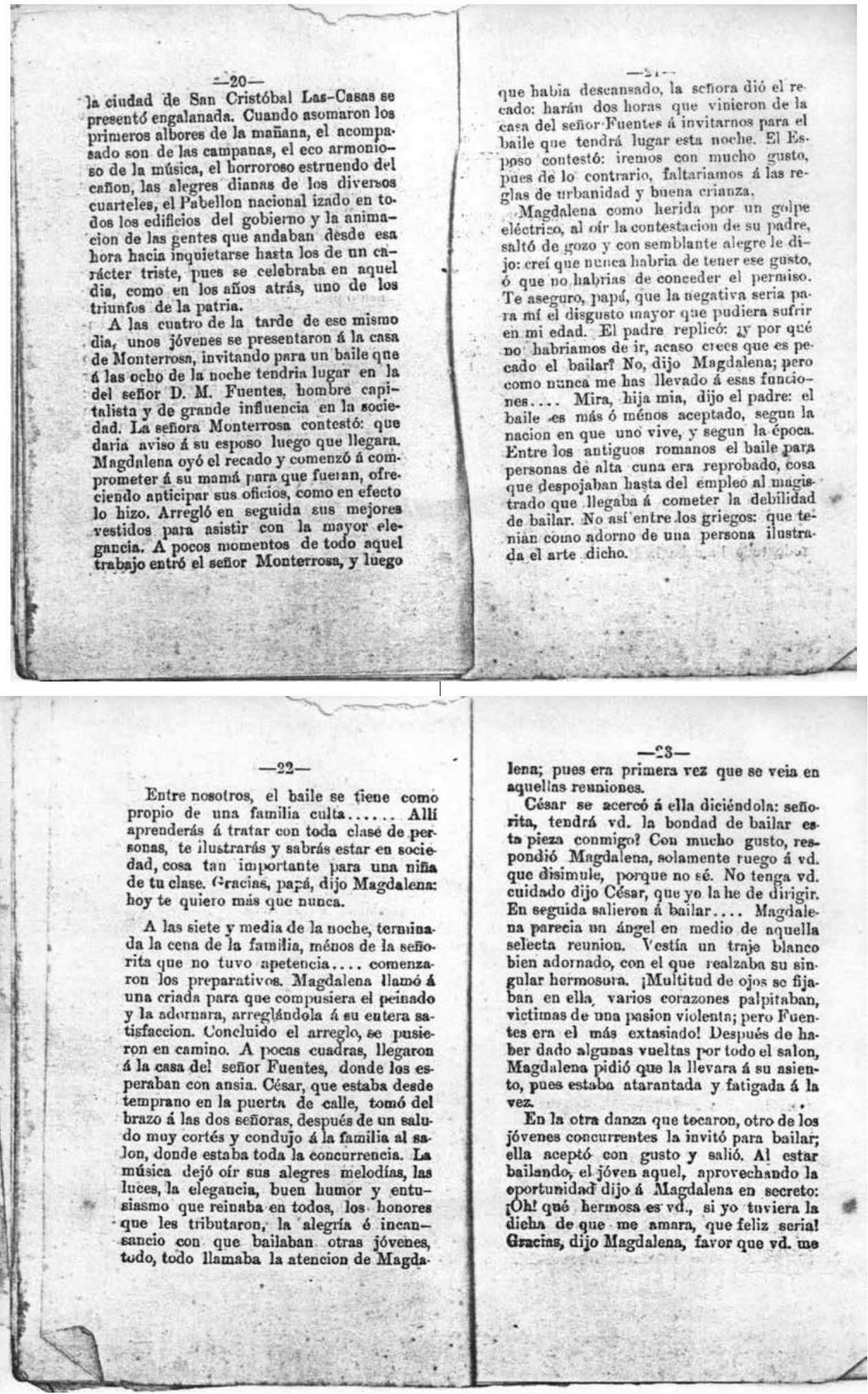




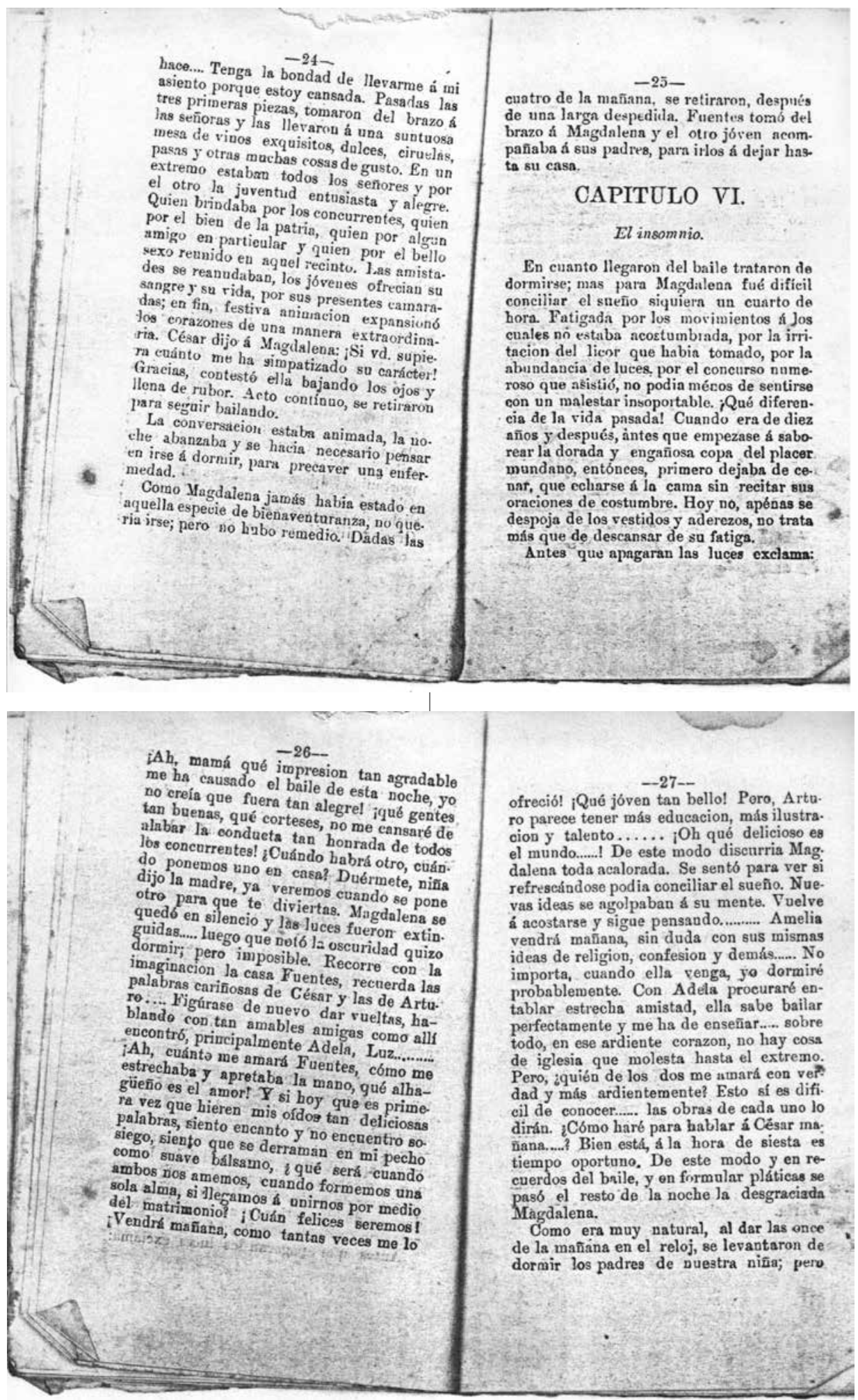




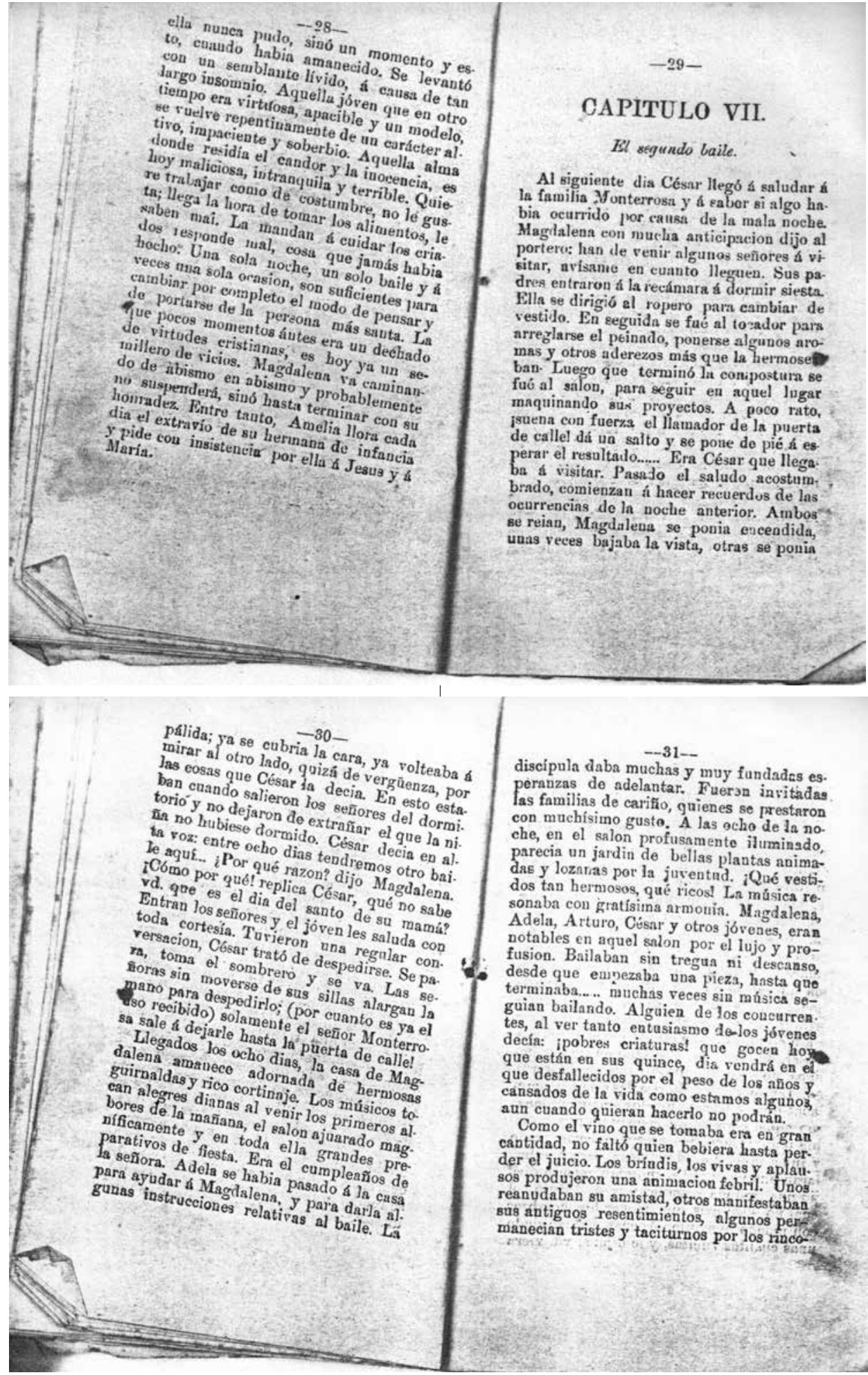




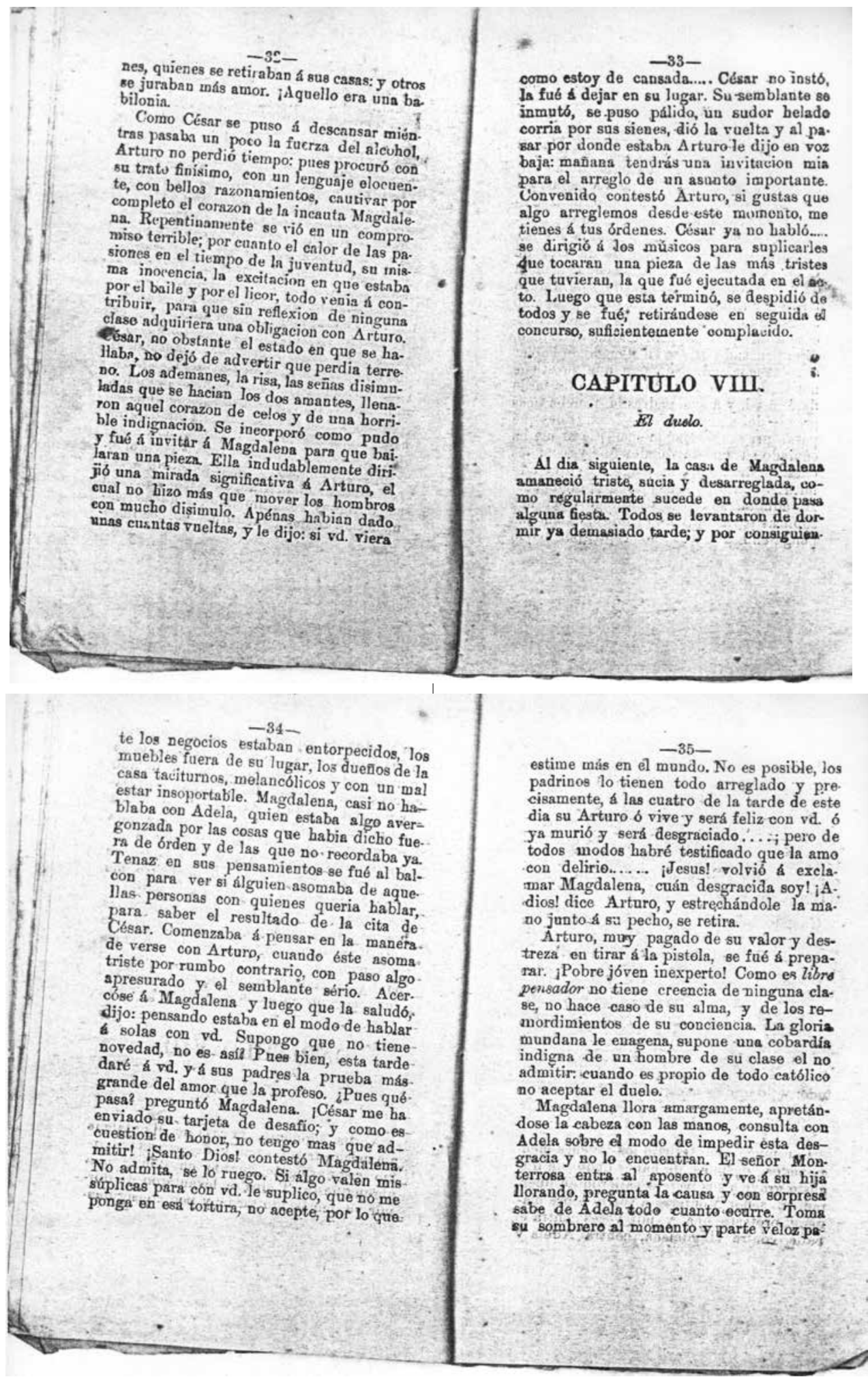




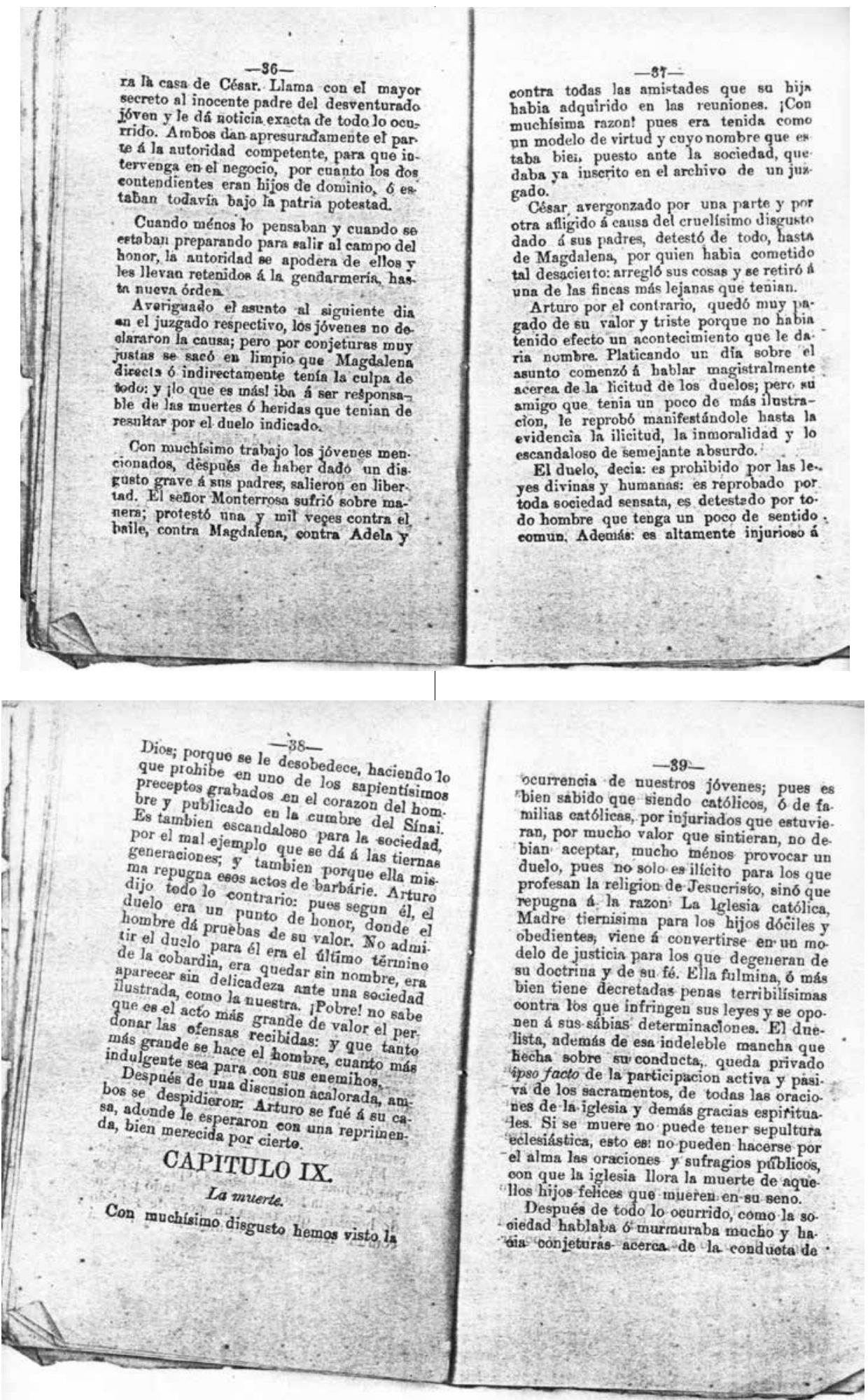




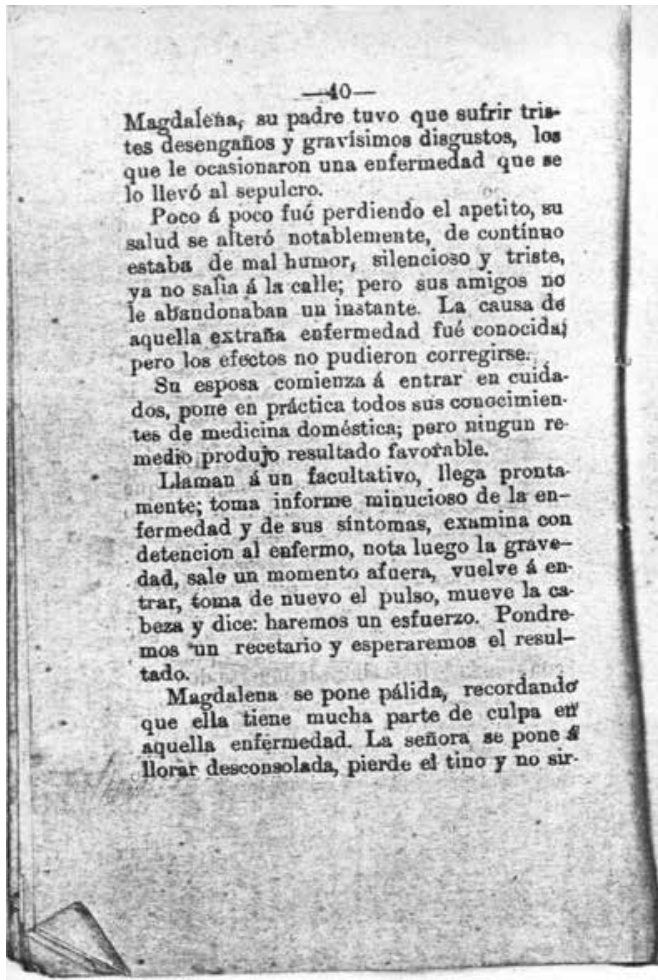

ve pora -11 -

- para nada por causa del llanto $y$ de ta

Acuden con los remedios con toda actiridád; pero en vase, la grasedad aumenta de hora en hora, haciendo crixis cumdo mí. nos lo esjernbain. Los anigos del etífirmo nfigidos prócutan una junta de niéficos parn discernir el métodó curativo, llaman al Notario público, le exhớtấn á que haga gú testamento para mayor seguridad de sa familia $y$ ministran al paciente cuartas medicinas pueden.

¡Cosn extraña! De todo se piensa, de to. do se babla en áquella casa, ménos de los rénedies đel espíritu, ménos de los Sacra. nientos. iNadié mienta confesion! Ilegat sns parienties profinuesen otra junta de mè. dicos, Jlamen uñ sacerdute, buscan un cru. cifljo, corren por nuevas medicinas; pero en Yano! Era demasiado tarde, el enfermo se habia gravado repentinamente con linereza admirnble, habin petdido una nocimiento y' el habla; estabh sordo, madta y casi insensiblu! Cormo á la hora de acuệ empeoraniento instautáné conienza ế es. tertor de la agonia, todós llorin nindan por una y otra parte, quien the

un mueble y lo eambia de su toggr, quim

\section{0}

ale á is calle sin tingun objeto, uno lla: mo a los criados, ótro los depide: unos $m a$ a los criados, des se - desesperan en vis. caen privadon, otros se desespeulo. ¡Tal la ta de aquel trististno espectactio. confusion que bay en aquella casate Enero A las ocho de la noclíe del 1\% de Enero de 1871, el señor Monterrosa nenbaba do de 1871, el śltimo suspiro. La casa fué ndor. exhalar el ultumos susto. Colocan el féretro nada con riguroso luto. Colocal $\mathrm{y}$ nlumbra. en medio de la sala prineipal, $y$ alumbro do por cirios encendidos, pruestos en her. nosos candelatros de oro, Be vein tambien. el retrato del difunto. Cada cortina blan. el retrato del difuuior es mezclada con craldas de ciprés: iAquel. sdornada con guirnaldas de cipré.

lúgubre aparato era conmovecar.

No pasaron muchos minutos para que la noticia circulara. Inmediataniente los demás parientes y anigos del finado rodérico su cadáver. Unos hacen el panegirico. otros lleran la pérdida, unos lamentan su oto otros dan constuelo a la familis dorliente.

oflente.

Haciendo el comcntario de su vida defec

su muerte, de cus virtudes y de sus del dia

tos pasaron la uoche y $\mathrm{g}$ ran 1 arte del dia

sgajente, liasta que se flega

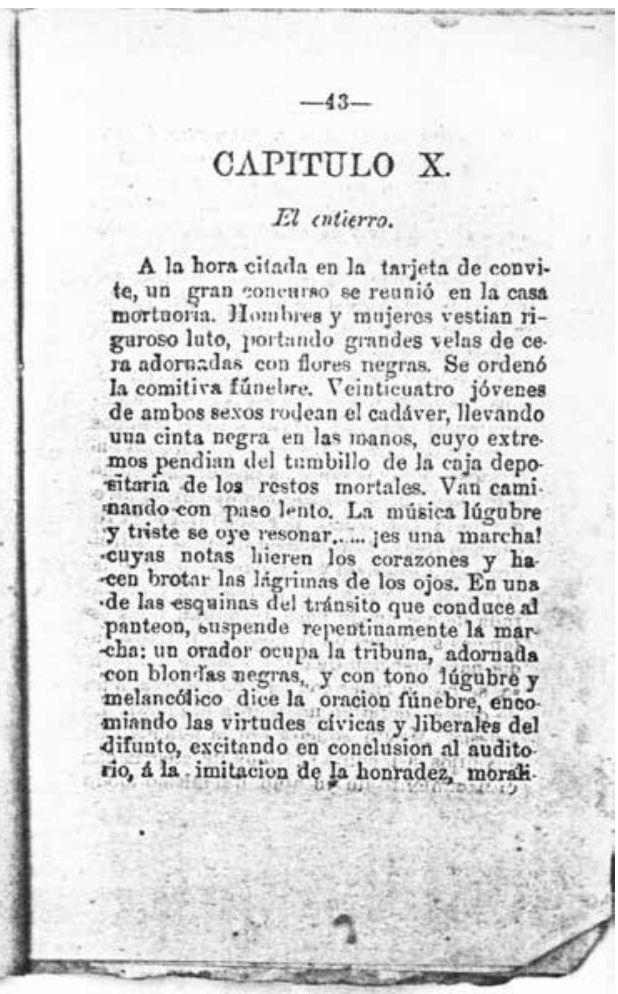

te, un gran concurao se reunió en la cass mortaoria, Jombires y mujercs vestinn rigaroso luto, jortando grandes velas de ce ra adornadas con flures negras. Se ordenb la comitira fúnebre. Veinticuatro jóvenes de ambos sexos rodean el cadáver, llevando un cint a negra en las manos, cuyo extre mos pendian del tumbillo de la caja depoeitaria de los restos mortales. Van cami. nando con paso lento. La música lúgubre triste se oye resonar..... jes una marcha! cuyas notas hieren los corazones y he een brotar lns lígrimas de los ojos. En un de las esquinas del tránsito que conduce a panteon, buspende repentinamente ls mar un orador ocupa la tribuna, adornad blonirs negrns, y con tono lúgubre o dice la oracion funebre, miando las virtudes cívicas y Jiberales de ifunto, excitando en conclusion al audito io, \& la -imitacion de $I_{a}$ hontades morat 

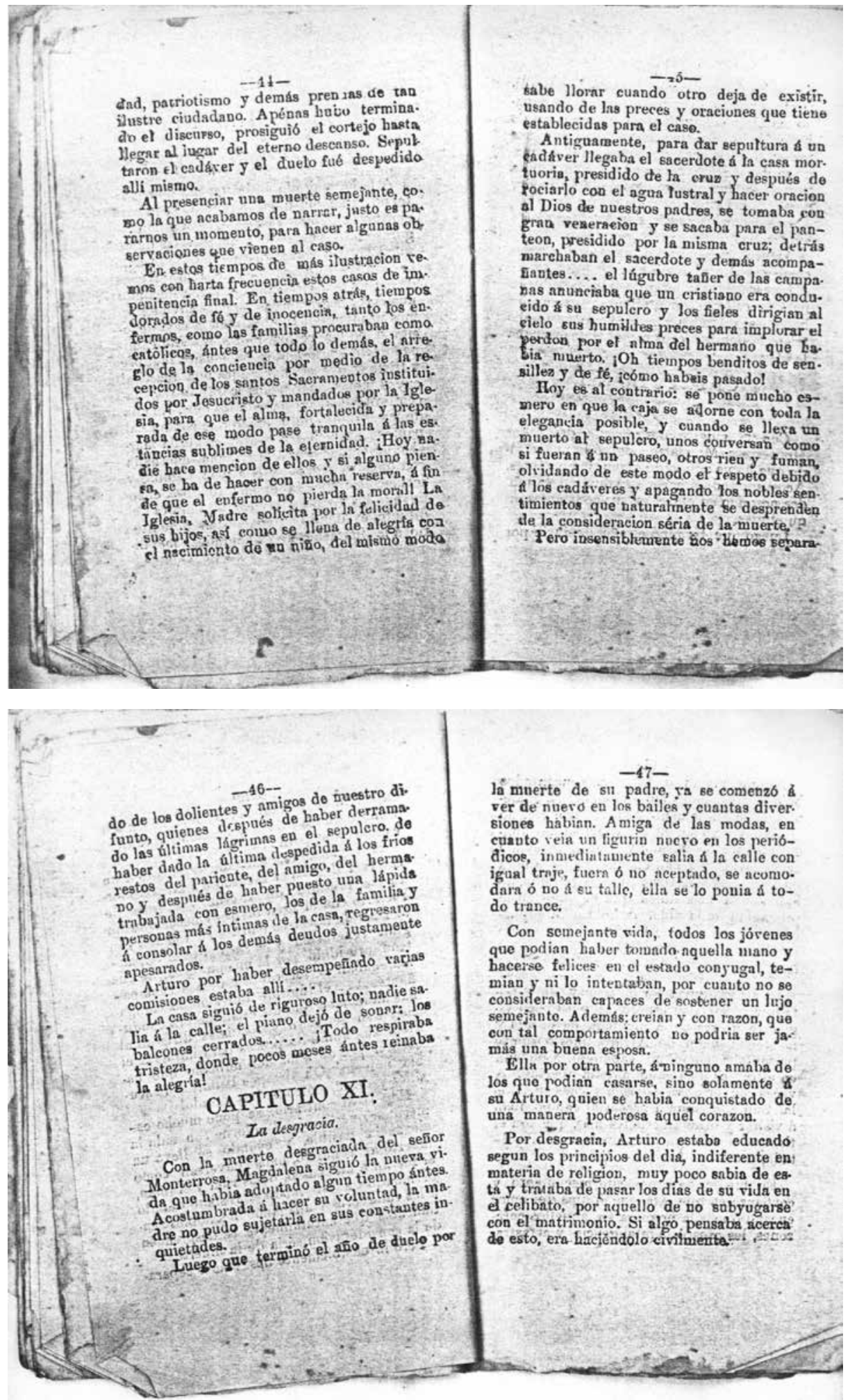


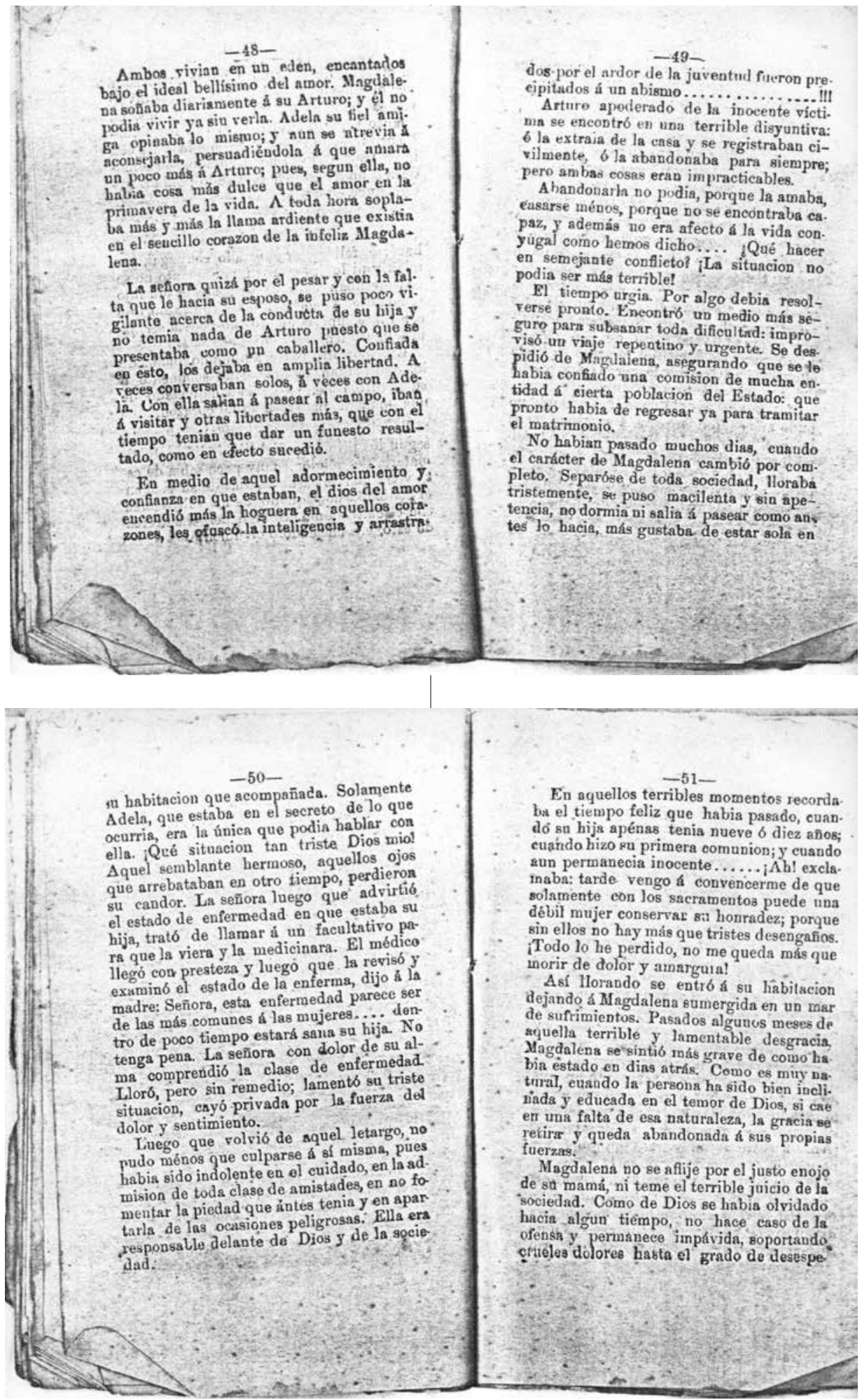




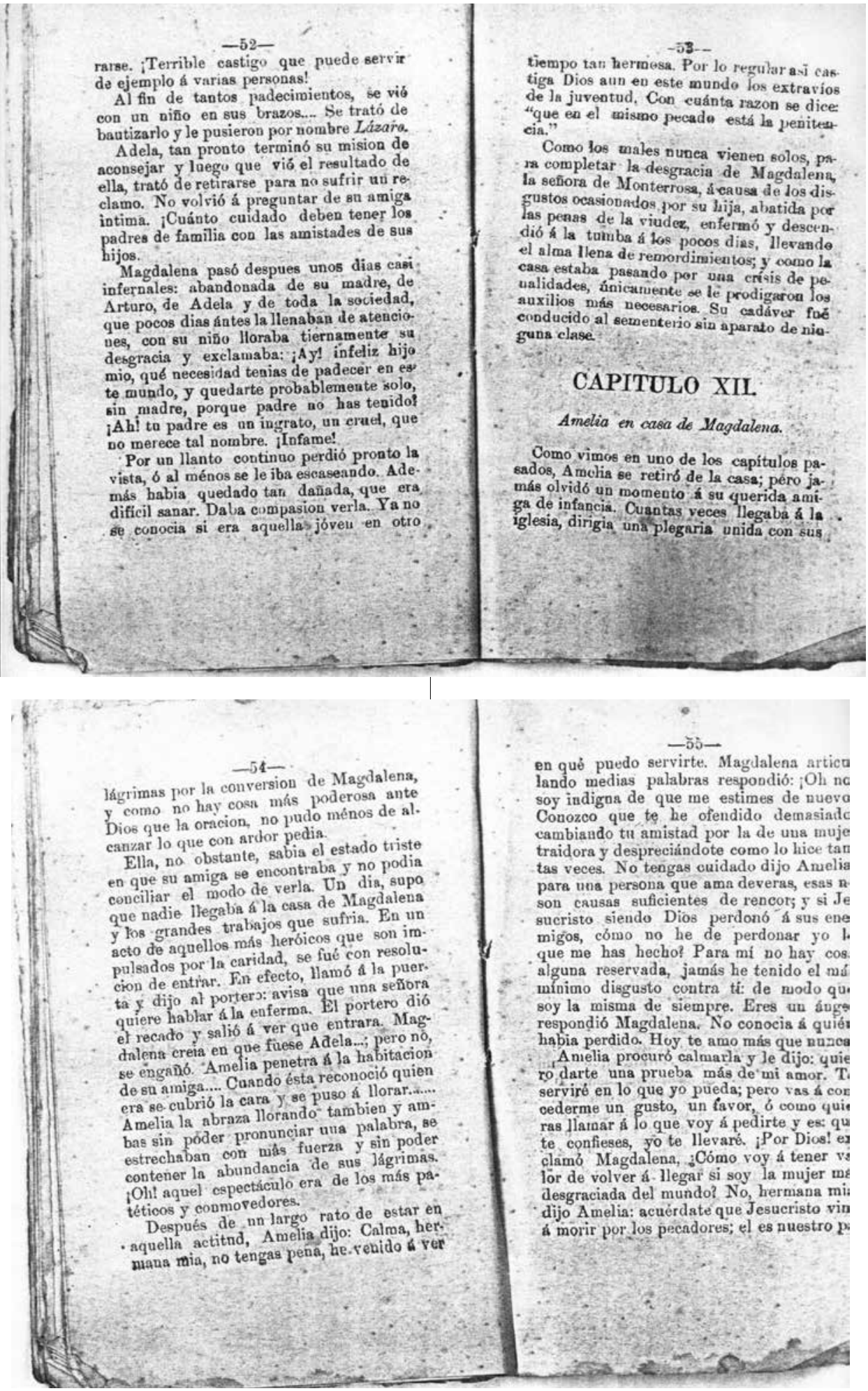

Revista LiminaR. Estudios Sociales y Humanísticos, vol. XVI, núm. 2, julio-diciembre de 2018, México, pp. 189-209. ISSN: 1665-8027. 